\title{
IAMJ
}

INTERNATIONAL

AYURVEDIC

MEDICAL JOURNAL

ISSN: 2320-5091

Impact Factor: 6.719

\section{A LITERARY REVIEW ON THE HEALTH BENEFITS OF THE INDIAN FIVE SPICE BLEND OR “PANCH PHORON” BASED ON AYURVEDIC CLASSICAL TEXTS}

\section{Nabaruna Bose}

PG Scholar, Dept. of Kayachikitsa, Govt. Ayurvedic College, Guwahati-14, Assam, India

Corresponding Author: bose.nabaruna@gmail.com

https://doi.org/10.46607/iamj1909032021

(Published online: March 2021)

Open Access

(C) International Ayurvedic Medical Journal, India 2021

Article Received: 23/02/2021 - Peer Reviewed: 28/02/2021 - Accepted for Publication: 06/03/2021

\section{(A) Check for updates}

\begin{abstract}
The green ecology around us is surrounded by various types of plants. India houses a wide variety of plants possessing medicinal properties which are known to us while some are yet to be discovered and used so that the human mankind need not be dependent on artificial and toxic chemicals. All over the world spices are used to flavour the food. These spices comprise different parts of the plant like seeds, bark, root, etc. They not only add flavour to the food but also act as a preservative and has immense health benefits too. Panch Phoron is a mixture of five spices- Cumin seeds (Jeeraka), Fennel seeds (Mishreya), Fenugreek seeds (Methika), Nigella seeds (Upakunchika) and Mustard seeds (Sarshapa). It is widely used in Eastern part of India on a daily basis for adding flavours to the food. Each individual ingredient in itself is beneficial for us. Ayurveda has a holistic approach. It believes in organic way of treatment by eliminating the toxins and balancing the Tridosha. The review aspires to scientifically validate the vast traditional use of this spice in the Eastern cuisine and its immense scope in herbal therapeutics.
\end{abstract}

Keywords: Ayurveda, Brihat trayee, Kaphavatashamak, Dipaniya 


\section{INTRODUCTION}

In prehistoric age, man started to use plants growing around them in various ways. Later on, with the advancement of knowledge their probable mode of action and their properties were studied scientifically. Ayurveda originated in India more than 5000 years ago and is called as the "The Science of Life". It places great emphasis on the prevention of a disease and maintenance of health by balancing the three doshas. Acharya Charaka has said that the real expert of medicinal plants is the one who is well versed in their use besides their names and forms. The five-spice blend or the "Panch Phoron" comprising of Jeeraka, Mishreya, Methika, Upakunchika and Sarshapa is a staple tempering spice in areas like West Bengal, Assam, Orissa and other parts of Eastern India. It was seen that the seeds have various properties such as anti-microbial, antioxidant, anti-inflammatory, antidiabetic and may be used for the treatment of diabetes, inflammation, renal disorders, liver disorders etc.

Aim: To study drug review of Panch phoron from Ayurvedic classical texts.

\section{Objectives:}

1. Collection of various references from the available Ayurvedic classical texts.

2. Highlighting the use and benefits of the same.

\section{Materials and Methods:}

The review has been done based on Brihat trayee, Dhanwantari Nighantu, Bhavprakash Nighantu, and other experimental and evidence-based research papers on Jeeraka, Methika, Mishreya, Upakunchika and Sarshapa.

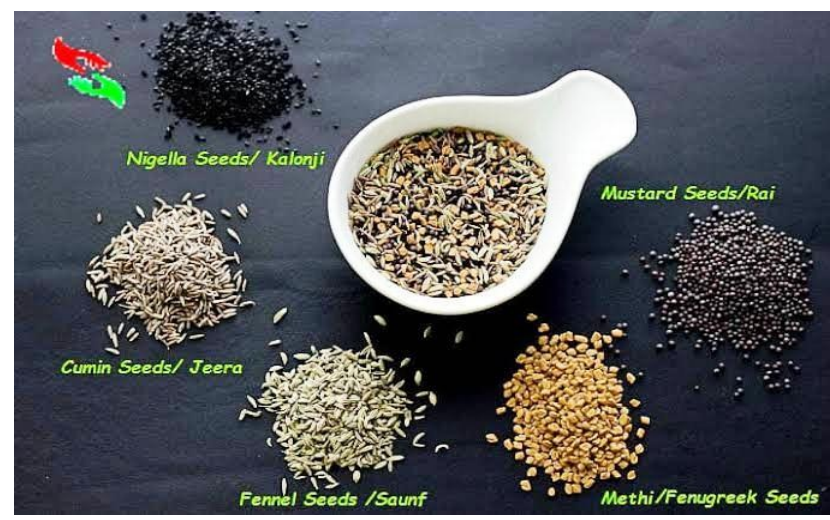

Fig. 1

Jeeraka
Botanical Name: Cuminum cyminum Linn. FAMILY: Umbelliferae, SYNONYMS: Ajaji, Kana, Jarana, Sukla ajaji, Dirgha Jeeraka, Ruchya , Dipaka.

Vernacular Names: Hindi: Jeera, Bengali: Jeera, Malayalam: Jeerakam, Telugu: Jeelakarra, Kannda: Jirige, English: Cumin seeds

Morphology ${ }^{[1]}$ Jeeraka is an annual cultivated herb, with an erecr, round, slender, branched stem about 30$60 \mathrm{~cm}$ long. It is native to and cultivated extensively in several places, mainly in arid and semi-arid climates, such as China, Egypt, Saudi Arabia and the Mediterranean, as well as India and Iran. However, the largest consumer of Cumin seed in the world is India. The leaves of cumin are multi-fid with long filiform segments. The flowers are small white or pink, overtopped by the bracts. The umbels both partial and general, consists of about 5 rays, with the involucres consisting of 2 or 3 filiform, 1 sided bract. The fruits are ovate or fusiform, of a light brown or greyish colour. The fruits are much longer than the pedicels, nearly tapering, but little contracted at the sides, fusiform, crowned by the short teeth of the calyx, densely upon the ridges, which are paler, filiform, and a little raised. The seeds are yellow to brownish-gray in colour and is elongated in shape with nine protuberances that possess numerous medicinal properties.

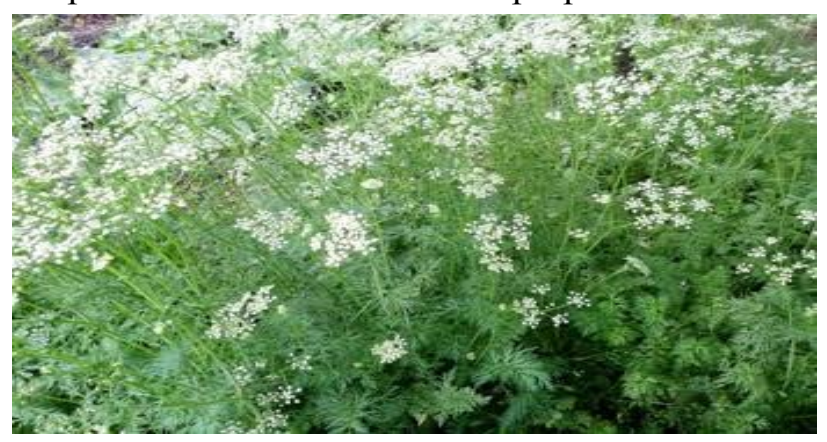

Fig. 2

\section{Phytochemistry}

The seeds contain aldehyde (60\%) fats, amino acids, flavonoids and glycosides (22\%), volatile oil(2-5\%) and the yellow coloured fresh oil contains cuminaldehyde as its chief component ${ }^{[2,3]}$. The cumin fruit contains resin, fatty matter, gum, lignin, protein bodies and salts, largely composed of malates, extractive and 
volatile oil. The proximate composition of the seeds indicates that they contain fixed oil, protein, cellulose, sugar, mineral elements and volatile oil ${ }^{[4]}$. The identified essential oils are octanol, limonene, thymol, anisyl alcohol, cuminaldehyde, anethole, vanillin and also benzoic acid. The presenting organic acids are aspartic, citric, malic, tartaric, propionic, ascorbic, oxalic, maleic and fumaric acids and phenols are salicylic acid, gallic acid, cinamic acid, hydroquinone, resorcinol, p-hydroxybenzoic acid, rutin, coumarine and quercetin. The cumin oil is used as a fragrance component in cosmetics ${ }^{[1]}$.

\section{Ayurvedic Pharmacology}

Rasa - Katu, Guna - Laghu, Ruksha, Virya - Usna, Vipaka - Katu Dosha karma - Kapha-vata hara

1. Jeeraka has been mentioned in Charaka Samhita in Shoolaprasaman mahakashaya and under Pippalyadi gana by Acharya Sushruta and Acharya Vagbhata.

2. Bhavprakash has mentioned Jeeraka as jwaraghna, pachaniya, vrishya, deepaniya, balya, ruchya, kaphahara, chaksushya and useful in treatment of Vatavyadhi, Adhmana,Gulma,Chardi Atisara ${ }^{[4]}$.

3. According to Rajnighantu, it is Krimighna, Agnidipaniya, Jirnajwarahara, Ruchya, Adhmannashaka ${ }^{[5]}$. Parts used: Fruits and seeds ${ }^{[6]}$. Dose: Powder 3-6 gm ${ }^{[6]}$.

\section{Pharmacological Activities of Jeeraka}

1. Ethanolic extracts of Cuminum cyminum has antibacterial effect against Staphylococcus aureus ${ }^{[7]}$.

2. Cuminum cyminum essential oils have a broad spectrum antifungal effect ${ }^{[8]}$.

3. In human eight weeks of intervention improved fasting blood glucose, glycosulated haemoglobin as well as serum levels of insulin ${ }^{[9]}$.

4. Antioxidant effect ${ }^{[10]}$.

5. Anti-inflammatory activity ${ }^{[11]}$.

Misreya

Botanical Name: Foeniculum vulgare Mill.

Family: Umbelliferae

Synonyms: Chatra, Madhurika, Shaleen, Misreya, Misi.

VERNACULAR NAMES:
- Hindi: Sounf

- Bengali : Mouri

- Tamil : Sombu

- Telugu : Sompu

- Kannada: Badisopu

- English: Fennel, Sweet fennel.

Morphology

Mishreya (Foeniculum vulgare) is a medicinal and aromatic plant belonging to the Apiaceae (Umbelliferae) family. It is a hardy, perennial-umbelliferous herb with yellow flowers and feathery leaves. It grows to a height of upto $2.5 \mathrm{~m}$ with hollow stems. The leaves grow upto $40 \mathrm{~cm}$ long; they are finely dissected with the ultimate segments filiform of about $0.5 \mathrm{~mm}$ wide. The flowers are produced in terminal compound umbels. The fruit is a dry seed 4-10 $\mathrm{mm}$ long ${ }^{[11]}$.

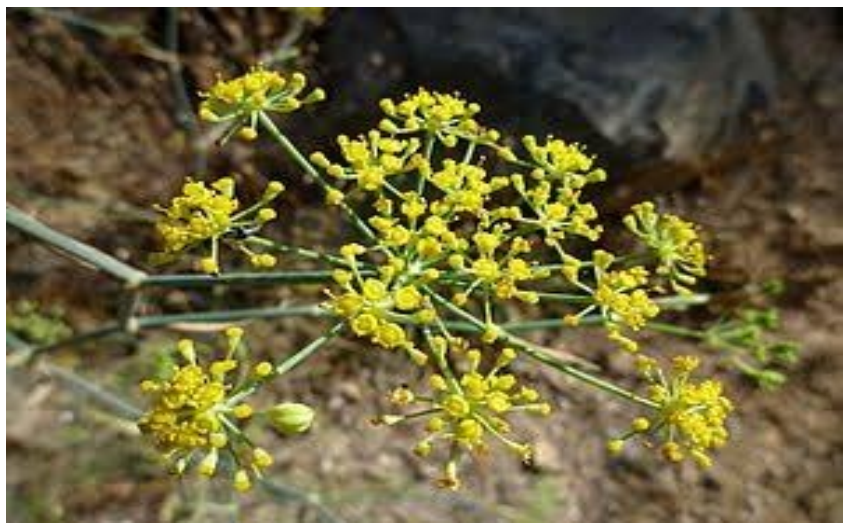

Fig. 3

\section{Phytochemistry}

- Seeds: All parts of fennel are used but the seeds are used especially. It contains $6.3 \%$ of moisture, $9.5 \%$ protein, $10 \%$ fat, $13.4 \%$ minerals, $18.5 \%$ fibre and $42.3 \%$ carbohydrates. The fennel seed essential oil is reported to contain trans-anethole, fenchone, estragol and a-phellandrene ${ }^{[13]}$.

- Leaves: The leaves contain minerals and vitamins such as calcium, potassium, sodium, iron, phosphorus, thiamine, riboflavin, niacin and vitamin $\mathrm{C}^{[14]}$.

- Fruits: Fruits contain $10-12 \%$ oil stored in the cotyledons of the seeds. Oil obtained from fennel fruit has palmitic acid, oleic acid, linoleic acid and petrocylic acid $^{[14]}$. The phenolic compounds present are 3-O-Caffeoylquinic acid, 4-O- 
Caffeoylquinic acid,5-O- Caffeoylquinic acid, 1,3-O-di- Caffeoylquinic acid. These are considered to be associated with the prevention of diseases thought to be induced by oxidative stress such as cardiovascular diseases, cancer and inflammation $^{[13]}$.

\section{Ayurvedic Pharmacology}

Rasa-Madhura, Katu, Tikta, Guna-Laghu, Ruksha, Virya - Usna, Vipaka - Madhura, Dosha karma Kapha-vata hara, Dipana-pachana, Hridya

1. Mishreya is mentioned in Madhuraskanda in Charaka Samhita.

2. Bhavprakash has mentioned it as Hridya, Agnimandyahara, good for Baddhavita (constipation), Krimi (Worm infestation). It managaes cough, vomiting and vatavyadhi $i^{[4]}$.

3. According to Kaiyadev Nighantu,along with Hridya effect, Mishreya can be used in Baddhavita, Krimi, Daha,Aruchi,Chardi,Kasa ${ }^{[6]}$.

Parts used - Fruit, Fruit oil, Roots, Stems, Leaves ${ }^{[6]}$

Dose - 3-6g (Fruit powder), 3-6g (root powder)5-10 drops (oil) and 20-40ml (distillate) ${ }^{[6]}$

\section{Pharmacological Activities of Mishreya}

1. Antibacterial activity ${ }^{[15]}$ Fennel has antibacterial activity due to compounds such as, linoleic acid, oleic acid, undecanal,1,3-benzenediol and 2,4undecadienal.

2. Antifungal activity ${ }^{[14]}$ Fennel extract has antifungal activity against various fungal species such as Candida albicans, species of Aspergillus and dermatophytes.

3. Antioxidant activity ${ }^{[16]}$ Fennel is known as an excellent source of natural antioxidants. It can inhibit free radicals due to high content of polyphenols and flavonoids. Phenolic compounds such as caffeoylquinic acid, rosmarinic acid, eriodictyol7-orutinoside, quercetin-3-O-galactoside showed antioxidant properties.

4. Hepato-protective activity ${ }^{[19]}$ The extract from the fennel plant has hepatoprotective effect by reducing the levels of AST (aspartate aminotransaminase), ALT (alanine aminotransaminase), ALP (alkaline phosphatase) and serum bilirubin.
5. Anti-inflammatory activity ${ }^{[17]}$ Oral administration of $200 \mathrm{mg}$ per $\mathrm{kg}$ of methanol extract of fennel fruit shows inhibitory effects on acute and subacute inflammatory disease and type 4 allergic reaction.

6. Anti-diabetic activity ${ }^{[18]}$ Aqueous extract of fennel is seen to lower blood sugar level and has anti diabetic activities.

\section{Methika}

Botanical Name: Trigonella foenum greacum Linn.

Family: Fabaceae Synonyms: Bahubeeja, Peeta beeja, Gandhaphala, Deepani, Bodhani, Jatigandhaphala, Municchada, Kunchika.

\section{Vernacular Names:}

- Hindi: Methi

- Bengali : Methi

- Tamil : Venthaayam, Vendayam

- Telugu : Mentulu

- Kannada: Menthya, Menthe

- Malayalam: Ventiyam, Uluva

- English: Fenugreek seeds.

\section{Morphology}

It is a plant native to India and South Europe. It is an aromatic annual plant, 30-60 $\mathrm{cm}$ in height, erect, slightly branched with tapering roots. The leaves are alternate, trifoliate, lanceolate and leaflets are shortly stalked blunt oblong. Flowers are whitish sessile, solitary in the axis of the leaves. Fruit pods are erect when young then bend downward with 10-20 seeds per pod. The seeds are hard, yellowish brown and angular. Some are oblong, some rhombic other virtually cubic, with a size of about $3 \mathrm{~mm}$.

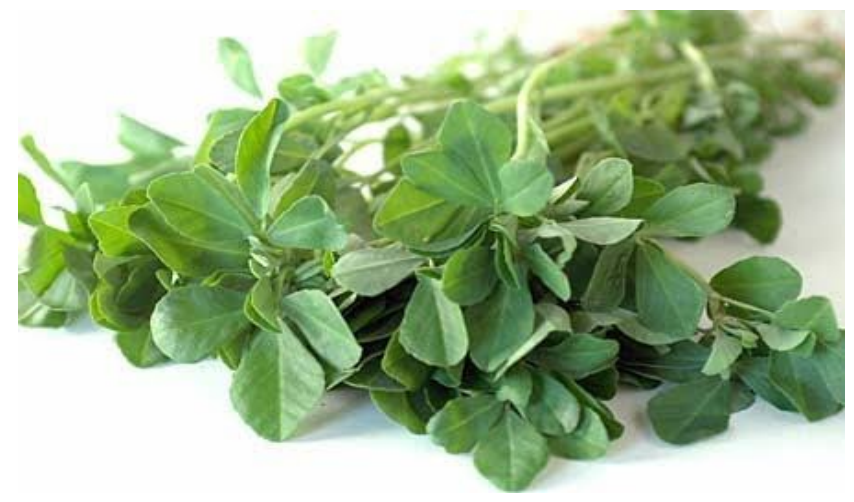

Fig. 4

Phytochemistry 
- Leaves: Leaves contain seven saponins known as graecunins. These compounds areglycosides of diosgenin. Leaves contain about $86.1 \%$ moisture, $4.4 \%$ protein, $0.9 \%$ fat, $1.5 \%$ minerals, $1.1 \%$ fibre and $6 \%$ carbohydrates. The minerals and vitamins present are calcium, iron, zinc, phosphorus, riboflavin, carotene, thiamine, niacin and vitamin $\mathrm{C}^{[20]}$.

- Seeds: The seeds contain about $0.1-0.9 \%$ of diosgenin, saponin (fenugrin B), several coumarin compounds as well as number of alkaloids like trigonelline, gentianine, carpaine ${ }^{[21]}$.

\section{Ayurvedic Pharmacology}

Rasa - Katu, Guna - Laghu, Snigdha, Virya - Usna, Vipaka - Katu, Dosha karma - Kapha-vata shamaka, Krimighna

1. Dhanwantari Nighantu has mentioned Methika as Vatashamani, Sleshmaghna, Jwaranashini, Arochakhara,Diptikara ${ }^{[6]}$.

2. Bhavprakash has mentioned it as Vata-kapha shamak and jwara nashak ${ }^{[4]}$.

Part used: Seeds, Whole plant ${ }^{[6]}$., Dose : 10-20 ml (Swaras) and 3-6 g (Churna $)^{[6]}$.

\section{Pharmacological Activities of Methika}

1. Hypoglycemic effect ${ }^{[22,26]}$

Dietary fibre from fenugreek blunts glucose after a meal. Fenugreek contains galactose and mannose which are associated with reduced glycemic effect. The hypoglycaemic effect has been especially documented in humans and animals with type1 and type 2 diabetes mellitus]. Oral administration of methanolic and aqueous extracts of seeds at a dose of one gram per kilogram body weight resulted in hypoglycaemic effect.

2. Hypocholesterolemic effect ${ }^{[22]}$ Fenugreek seeds contain large amount of fiber galactose and mannose are the main composition of gum which is associated with reduced cholesterol.

3. Antioxidant activity ${ }^{[24]}$

It has been reported that Fenugreek seed extract with methanol, ethanol, dichloromethane, acetone, hexane and ethyl acetate has a radical scavenging activity.

4. Anticancer effect ${ }^{[27]}$
Fenugreek seed extracts significantly inhibited 7,12dimethylbenzanthracene-induced mammary hyperplasia and reduces its incidence in rats and advised that anti breast cancer protective effects of fenugreek could be due to increased apoptosis.

5. As a digestive ${ }^{[25]}$

Spices consumed in diet positively influenced pancreatic digestive enzymes. Pancreatic lipase activity is seen to be enhanced in rats, on feeding rats with spicy diets for eight weeks.

6. Lactation aid ${ }^{[23]}$

Fenugreek has been found to stimulate sweat production as it contains hormone precursor to increase milk formation. It has been reported that fenugreek can increase a nursing mother's milk supply within $24-72 \mathrm{~h}$ after first taking the herb.

\section{Upakunchika}

Botanical Name: Nigella sativa Linn., Family: Apiaceae, Synonyms: Kalajaji, Kalika, Karavi, Prithvika, Bashpika

\section{Vernacular Names:}

Hindi: Kalonji, Bengali: Kalojeera, Tamil : Karun Jeeragam, Telugu: Nalla jeelakarra, Malayalam : Karun jeeragam, English: Onion seeds, Small fennel, Black onion seeds

\section{Morphology}

Nigella sativa is an annual flowering plant grows at $20-90 \mathrm{~cm}$ tall, with finely divided leaves; the flowers are white, yellow, pink, pale blue or pale purple color, with 5-10 petals. The fruit is a large and inflated capsule consists of 3-7 united follicles, each containing several seeds ${ }^{[28]}$. Seeds are small dicotyledonous, trigonus, angular, tubercular, black externally and white inside, odor slightly aromatic and taste bitter ${ }^{[29]}$.

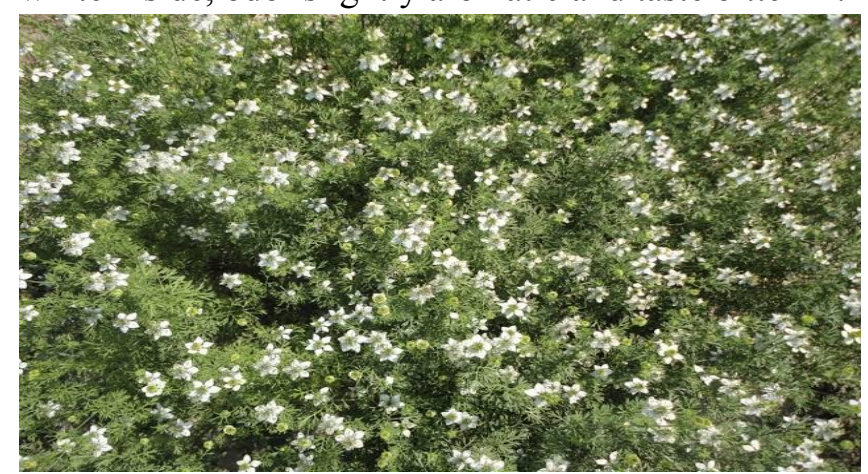

Fig. 5 


\section{Phytochemistry}

The most important active constituents are thymoquinone $(30 \%-48 \%)$, thymohydroquinone, dithymoquinone, p-cymene $(7 \%-15 \%)$, carvacrol $(6 \%-12 \%)$, 4 terpineol $(2 \%-7 \%)$, tanethol $(1 \%-4 \%)$, sesquiterpene • longifolene (1\%-8\%) $\alpha$-pinene and thymol etc. Seeds contain two different types of alkaloids, i.e. isoquino- • line alkaloids e.g. nigellicimine and nigellicimine- Noxide, and pyrazol alkaloids or indazole ring bearing alkaloids which include nigellidine and nigellicine. Moreover, N. sativa seeds also contain alpha-hederin, a water soluble pentacyclic triterpene and saponin, a potential anticancer agent ${ }^{[30]}$.

Ayurvedic Pharmacology

Rasa - Katu,Tikta

Guna-Laghu, Ruksha

Virya - Usna

Vipaka-Katu

Dosha karma - Kapha-vata shamaka, Krimighna, Dipana, Pachana, Gulmahara, Adhmannashaka

Parts used : Seeds ${ }^{[6]}$

Dose: $1-3 g$ (powder) ${ }^{[6]}$

\section{Pharmacological Activities of Upakunchika}

1. Antibacterial activity ${ }^{[35]}$

The most effective extracts of N. sativa were the crude alkaloid and water extracts. Gram negative isolates were more susceptible than the gram positive ones.

2. Antifungal activity ${ }^{[31]}$

The aqueous extract of N. sativa seeds exhibits inhibitory effect against candidiasis in mice.

3. Antioxidant and antiarthritic activity ${ }^{[34]}$

Oral administration of thymoquinone significantly reduced the levels of pro-inflammatory mediators [IL$1 \beta$, IL- 6, TNF- $\alpha$, IFN- $\gamma$ and PGE (2)] and increased level of IL-10.

4. Cardiovascular activity ${ }^{[32]}$

Thymoquinone also averted the decrease in platelet numbers and the prothrombotic events.

5. Hepato-protective activity ${ }^{[33]}$

Aqueous extract of the seeds of N. sativa were evaluated for hepatoprotective activity in male Wistar rats against carbon tetrachloride induced hepatotoxicity.

Sarshapa

Botanical Name: Brassica juncea L.Czern.et Cosson.
Family: Cruciferae

Synonyms: Siddharta, Rajika phala, Katuka, Katu sneha, Bhutaghna, Tantubha

Vernacular Names:

Hindi: Sarson

Bengali: Shorsho

Tamil : Karuppukkadugadi

Kannada : Sasive

English : Wild turnip

\section{Morphology}

It is an annual herb with yellow flowers and being cultivated in most parts of India. It has long erect branches. Leaves are petaloid, green, ovate to obovate with 1-2 lobes or leaflets on each side and a larger sparsely setose, terminal lobe ${ }^{[6]}$.

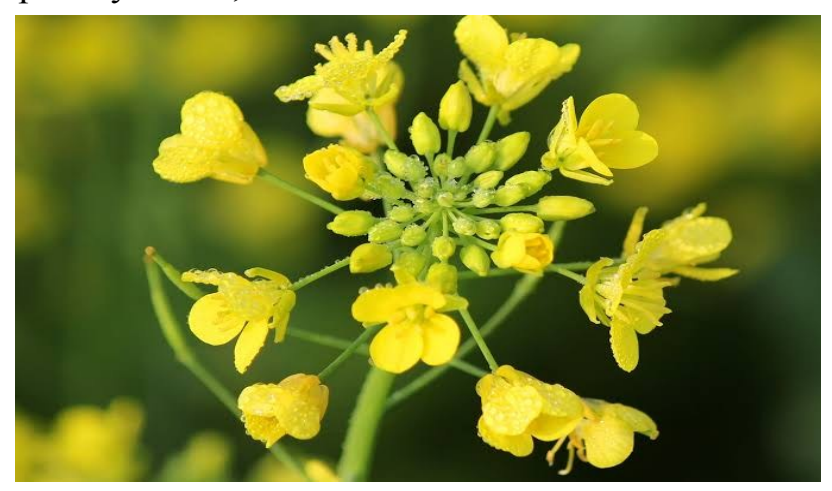

Fig. 6

\section{Phytochemistry}

Leaves: Leaves contain flavonoids, terpenoids, tannins, reducing sugars, vitamin $\mathrm{C}$, benzenepropanoic acid and n-tetrateracontane. It enhances the antioxidant activity.

Seeds: Seeds contain sinigrin, quercetin, catechin, sophoroside glucoside and vitamin E and seed oil possess antioxidant activity ${ }^{[36]}$.

Ayurvedic Pharmacology

Rasa - Katu,Tikta

Guna-Laghu, Snigdha

Virya-Usna

Vipaka-Katu

Dosha karma - Kapha-vatashamaka, Krimighna, Kusthaghna, Kandughna, Vidahi, Vamaka

Parts used: Seeds, Seed oil ${ }^{[6]}$, Dose: $2-4$ g (powder) ${ }^{[6]}$ 


\section{Pharmacological activities of Sarshapa ${ }^{[37]}$}

1. Wound healing activity

Sinigrin has potential to cure wounds.

2. Anti inflammatory activity

Flavonoids presents are responsible for the effect.

3. Anti oxidant activity

4. Hypo glycemic activity

Effect was documented in rats fed with mustard diet for 60 days.

\section{DISCUSSION}

Panch phoron is a mixture of five spices widely used in daily cooking. The present study delves into the various health benefits of the five seeds comprising panch phoran. According to Ayurveda, prevention of disease and maintaining health is the main aim. Imbalance of the dosha is the main cause of any disease and balancing them helps in treating the condition. It was seen that the seeds have properties such as Kapha vata shamak, Kusthaghna, Krimighna, Deepana, Agnimandyahara, Pachana, Kandughna, Ruchikara, Jawarahara and pharmacological activities such as Anti-microbial, anti-fungal, antioxidant, antiinflammatory, hepatoprotective and anti-cancer.

\section{CONCLUSION}

Ayurveda is based on holistic approach to the treatment of disease. Panch Phoron or the five-spice blend has activities such as Antioxidant, anti-diabetic, hepatoprotective, anti-cancer and gastroprotective activity. This article has tried to focus on the health benefits of each ingredient of panch phoron or the Indian five spice blend and therefore it can be used for the treatment of diabetes, hepatic disorders and many more and for this more study needs to be done.

\section{REFERENCES}

1. Singh RP, Gangadharappa HV, Mruthunjaya K. Cuminum cyminum - A Popular Spice: An UpdatedReview. Pharmacogn J.2017;9(3):292-301.

2. Iacobellis NS, Cantore PL, Capasso F, Senatore F. Antibacterial activity of Cuminum cyaminum L. And Carum carvi L. Essential oils. J Agric Food Chem 2005; 53: $57-61$.
3. El-Kani M, Fereshteh G, Mehdi M, Soosan R. Extraction of volatile oil from cumin (Cuminum cyminum L.) with superheated water. Journal of food process engineering 2007; 30(2): 255-266.

4. Bhavprakash Nighantu, Purvakhanda, Haritkyadi Varga

5. Tripathi ID, Rajanighantu of Pandit Narahari, Chowkhamba Krishnadas Academy, Varanasi $5^{\text {th }}$ edition, 2010.

6. Sharma P V, Dravyaguna vijnana, Volume II, Chaukhamba Orientalia, Reprint Edition:2012

7. Mostafa A.A., Antimicvrobial activity of some plant extracts against bacterial strains causing food poisoning diseases. Saudi Journal of Biological Sciences. 2018; 25(2): 361-366.

8. Taghizadeh S.F., Coronatine elicitation alters chemical composition and biological properties of cumin seed essential oil. Microbial Pathogenesis.2019;130:253258.

9. Tahir HU., Chemical Composition and Antidiabetic Activity of Essential oils Obtained from Two species (Syzygium aromaticum and Cuminum cyminum). International Journal of Food Properties.2016; 19(10):2156-2164.

10. Moghaddam M., Miran S.N.K., Pirbalouti A.G., Mehdizadeh L., Ghaderi Y., Variation in essential oil composition and antioxidant activity of cumin fruits during stages of maturity, Industrial Crops and Products.2015;70: 163-169.

11. Srinivasan K., Cumin and black cumin seeds: traditional uses, chemical constituents and nutraceutical effects. Food Quality and Safety.2018;2(1): 1-16.

12. Manzoor A. Rather, Mushtaq A. Qurishi, Foeniculum vulgare: A comprehensive review of its traditional use, phytochemistry, pharmacology and safety. Arabian Journal of Chemistry.Volume 9 , Supplement 2, November 2016

13. Z.M. Anka, et al. "Phytochemistry and Pharmacological Activities of Foeniculum vulgare". IOSR Journal of Pharmacy (IOSRPHR), 10(1), 2020.pp. 01-10

14. Rahimi R, Ardekani MRS. Medicinal properties of Foeniculum vulgare Mill. in traditional Iranian medicine and modern phytotherapy. Chin J Integr Med 2013; 19(1): 73-9.

15. Esquivel-Ferriño PC, Favela-Hernández JMJ, GarzaGonzález E, Waksman N, Ríos MY, CamachoCorona MdR. Antimycobacterial activity of constituents from Foeniculum vulgare var. dulce grown in Mexico. Molecules 2012; 17(7): 8471-82. 
16. Parejo I, Jauregui O, Sánchez-Rabaneda F, Viladomat F, Bastida J, Codina C. Separation and characterization of phenolic compounds in fennel (Foeniculum vulgare) using liquid chromatography-negative electrospray ionization tandem mass spectrometry. J Agric Food Chem 2004; 52(12): 3679-87

17. Choi EM, Hwang JK. Antiinflammatory, analgesic and antioxidant activities of the fruit of Foeniculum vulgare. Fitoterapia 2004; 75(6): 557-65.

18. Sushruta K, Satyanarayana S, Srinivas S, Sekhar JR. Evaluation of the blood-glucose reducing effects of aqueous extracts of the selected umbelliferous fruits used in culinary practices. Trop J Pharm Res 2007; 5(2): 613-7.

19. Ozbek H, Ugras S, Bayram I, Uygan I, Erdogan E, Ozturk A, et al. Hepatoprotective effect of Foeniculum vulgare essential oil: A carbon-tetrachloride induced liver fibrosis model in rats. Scand $\mathrm{J}$ Lab Anim Sci 2004; 31(1): 9-17.

20. A.V. Rao. Herbal Cure for Common Diseases, Fusion Books, New Delhi (2003), Google Scholar.

21. Yadav et al., The health benefits of Trigonella foenumgraecum: a review. Int.J.Eng.Res.Appl.,1(1)(2011),pp.32-35

22. KT Roberts, The Potential of Fenugreek as a functional food and nutraceutical and its effect on glycemia and lipidemia. J.Med. Food, 14 (12)(2011),pp.1485-1489

23. H.S. Snehalata, D.R. Payal, Fenugreek (Trigonella foenum-graecum L.):an overview. Int.J.Curr.Pharm.Rev.Res.,2(4)(2012),pp.169-187

24. S.B. Bukhari, I.B. Muhammad, M. Sahabuddin. Antioxidant activity from the extract of fenugreek seeds. Pak.J.Anal.Environ.Chem.,9 (2)(2008),pp.78-83

25. K. Platel, K. Srinivasan. Influence of dietary spices and their active principles on pancreatic digestive enxymes in albino rats.Nahrung,44(2000),pp 42-46

26. T.Zia, S.N. Hasnain. S.K. Hasan. Evaluation of the oral hypoglycaemic effect of Trigonella foenum-graecum L.(methi) in normal mice. J. Ethnopharmacol.,75(2001).pp. 191-195

27. A. Amin, A. Alkaabi, S. Al-Falasi, S.A. Daoud. Chemopreventive activities of Trigonella foenum-graecum against breat cancer. Cell.Biol.Int.,29(2001), pp.687694

28. Goreja WG. Black seed nature's miracle remedy. New York, NY 7 Amazing Herbs Press, 2003.

29. Warrier PK, Nambiar VPK, Ramankutty. Indian medicinal plants-a compendium of 500 species. Chennai Orient Longman Pvt Ltd; 2004; 139-142.
30. Al-Jassir MS. Chemical composition and microflora of black cumin (Nigella sativa L.) seeds growing in Saudi Arabia. Food Chem 1992; 45:239-242.

31. Bita A, Rosu AF, Calina D, Rosu L, Zlatian O, Dindere $\mathrm{C}$ et al. An alternative treatment for Candida infections with Nigella sativa extracts. Eur J Hosp Pharm. 2012; 19:162

32. Nemmar A, Al-Salam S, Zia S, Marzouqi F, AlDhaheri A, Subramaniyan D et al. Contrasting actions of diesel exhaust particles on the pulmonary and cardiovascular systems and the effects of thymoquinone. $\mathrm{Br}$ J Pharmacol. 2011; 164(7):1871-1882

33. Mohideen S, Ilavarasan R, Sasikala E, R Thirumalai KR. Hepatoprotective Activity of Nigella sativa Linn. Indian journal of pharmaceutical sciences. 2003; 65(5):550-551.

34. Umar S, Zargan J, Umar K, Ahmad S, Katiyar CK, Khan HA. Modulation of the oxidative stress and inflammatory cytokine response by thymoquinone in the collagen induced arthritis in Wistar rats. Chem Biol Interact $2012 ; 197(1): 40-46$

35. Hannan A, Saleem S, Chaudhary S, Barka M, Arshad MU. Anti-bacterial activity of Nigella sativa against clinical isolates of methicillin resistant Staphylococcus aureus. J Ayub Med Coll Abbottabad. 2008; 20(3):7274.

36. Haq Nawaz, Muhammad Aslam Shad, Saima Muzaffar. Phytochemical Composition and Antioxidant Potential of Brassica.

37. https://www.drugs.com/npp/mustard.html

\section{Source of Support: Nil \\ Conflict of Interest: None Declared}

How to cite this URL: Nabaruna Bose et al: A Literary Review On The Health Benefits Of The Indian Five Spice Blend Or "Panch Phoron" Based On Ayurvedic Classical Texts. International Ayurvedic Medical Journal \{online\} 2021 \{cited March, 2021\} Available from: http://www.iamj.in/posts/images/upload/633 640.pdf 